\title{
The Effect of War on Law-What happens to their treaties when states go to war?
}

\author{
Arnold Pronto*
}

War is the ultimate game-changer. It leads to a rupture in the relations between states. This includes, potentially, a disruption of their legal relations as established in treaties (and may even affect those with third states). This was noted for example, by the Eritrea-Ethiopia Claims Commission, established to settle international claims arising from the war between the two states, which pointed out that 'the Parties' bitter international armed conflict [had] fundamentally changed the nature of their relationship....' Many wars have radically realigned the underlying bases of treaties to the extent that their original rationale can no longer be sustained, resulting in their modification or even termination. ${ }^{2}$ History also provides examples, as recent as the conflicts of the twentieth century, of states going to war precisely to shrug off the yolk of onerous treaties. For example, Germany initiated the Second World War ostensibly as a consequence of the onerous provisions imposed on it by the Versailles Treaty-and in so doing brought about the demise of the international regime established by that treaty.

Yet, such an outcome (abrogation) has not always been the automatic consequence of the outbreak of war. Some treaties have continued to apply during the armed conflict, owing to their purpose as, for example, in the case of treaties aimed precisely at regulating the conduct of belligerents, such as the Geneva Conventions of 1949, or guaranteeing the rights of neutrals in the case of war. ${ }^{3}$ More recently, this has been extended to include treaties

\footnotetext{
Senior Legal Officer, United Nations, Office of Legal Affairs. Member of the Secretariat of the International Law Commission. The views expressed herein do not necessarily reflect those of the United Nations, including the International Law Commission (unless otherwise indicated).

1 Civilians Claims by Eritrea, Partial Award of 17 December 2004, para 38, XXVI RIAA 195, 214.

2 D O'Connell, International Law, vol 1 ( $2^{\text {nd }}$ ed, 1970) 270.

3 See 'Codification of International Law' (1935) 29 Suppl. AJIL 664, Art 35(a); G Schwarzenberger \& E Brown, A Manual of International Law (6 $6^{\text {th }}$ ed, 1976) 139.
}

Copyright $\odot$ the Author(s).

This work is licensed under a Creative Commons Attribution-NonCommercial-NoDerivs 3.0 License. 
regulating diplomatic relations. ${ }^{4}$ Contemporary international law recognises an intermediate position, whereby treaties between parties to an armed conflict might be automatically suspended for the duration of the conflict, ${ }^{5}$ only to be revived afterwards, even if in a modified form, to reflect the new post-conflict modus vivendi. For example, the revival of certain pre-war treaties was dealt with (to varying degrees) in some of the peace treaties negotiated following the two world wars, ${ }^{6}$ sometimes in a manner favourable to the victorious powers, as in the case of the Italian Peace Treaties following the Second World War. ${ }^{7}$

As a general proposition, states which were previously involved in an armed conflict do not comprehensively regulate the legal outcome of the conflict, or do so only in relation to some of their treaties. ${ }^{8}$ Furthermore, while examples exist of courts and arbitral tribunals considering the fate of particular treaties in the wake of a war, they are likewise rare and have, on several occasions, occurred decades after the end of the conflict. For example, the effect of the Second World War on several extradition treaties was only determined by an Italian Court in 1970. ${ }^{9}$ Likewise, the question of the legal effect of the War of 1812 on the Jay Treaty of 1794 was the subject of consideration by various courts in the United States of America, including its Supreme Court, well into the twentieth century. ${ }^{10}$ For many conflicts, the question of the legal effect on the treaties between the

4 United States Diplomatic and Consular Staff in Tehran (United States v Iran), ICJ Reports $1980 \mathrm{p}$ 3, para 86. Here, the International Court of Justice emphasised the inviolability of diplomatic envoys and premises '[e]ven in the case of armed conflict'.

5 The North Atlantic Coast Fisheries case, Award of 7 September 1910, XI RIAA 167, 181. Recent practice has confirmed that bilateral treaties of a political or economic nature would typically be suspended by an armed conflict. See Economic Loss throughout Ethiopia, Partial Award of 19 December 2005, para 18, XXVI RIAA 445, 455.

6 Schwarzenberger \& Brown, above n 3, 139.

7 Art 44 of the Peace Treaty concluded on 10 February 1947 between Italy and the Allied Powers, awarding the latter the sole right to declare which pre-war bilateral treaties with Italy survived the war; as between Germany and Italy treaties covering private rights were considered by both countries to have been revived, cited in O'Connell, above n 2, 270. See C Parry, 'The Law of Treaties', in M Sørenson (ed), Manual of Public International Law (1968) 175, 237-8.

8 See H Briggs, The Law of Nations: Cases, Documents and Notes ( $2^{\text {nd }}$ ed, 1953) 943-4, for a discussion of the practice concerning the revival of treaties following the First World War in the context of the Treaty of Versailles.

9 In re Barnaton Levy and Suster Brucker, Court of Appeal Milan (30 October 1970), (1975) 1 Italian YIL 233, cited in Memorandum of the United Nations Secretariat on the Effects of Armed Conflicts on Treaties, UN Doc A/CN.4/550, 2005, para 5, in which the example is also provided of a 1977 judgment of a British Court where the effect of the Second World War on a 1927 convention was assessed.

${ }^{10}$ See, e.g. Karnuth v US 279 US 231 (1929). 
opposing parties has still to be addressed.

Such relative lack of practice has constrained the development of applicable rules of general international law. As recently as 2008, the law on the subject was generally considered to be uncertain. ${ }^{11}$ This is compounded by the fact that contracting parties hardly ever expressly provide in the treaty for the possibility of a violent disruption in their relations. ${ }^{12}$ The vast majority of treaties registered with the United Nations (at present, numbering in the tens of thousands) are silent as to the possible legal impact of the outbreak of armed conflict between the respective parties. Additional complexity arises from the fact that, in the contemporary international system, treaty relations between states are often established in a multilateral context. This calls for an appreciation of the difference between the effect on treaty relations arising under a multilateral treaty, as opposed to that on the treaty itself. In other words, while an armed conflict may result in the suspension of treaty relations, arising under a multilateral convention, between the parties to the conflict, there is no reason why the armed conflict should equally affect the operation of the treaty between third states parties to the treaty. ${ }^{13}$ At the same time, it is conceivable that the armed conflict could affect the treaty relations, arising under the multilateral treaty, between the parties to the conflict and third states. The legal position of third states might likewise be affected in situations of internal armed conflicts where only one state is engaged in an armed conflict (within its borders).

Contemporary reflection on these and other questions pertaining to the effect of armed conflicts on treaties has been relatively sparse. This was not always the case. In the first half of the twentieth century (particularly during the inter-war period) the legal effects of war was frequently considered. ${ }^{14}$ This can be explained, in part, by the fact that, up until the 1920s, the default position in international law was that the resort to war was prima facie lawful. ${ }^{15}$ The

${ }_{11}$ I Brownlie, Principles of International Law (7 $7^{\text {th }}$ ed, 2008) 620; A Aust, Modern Treaty Law and Practice ( $2^{\text {nd }}$ ed, 2007) 308.

12 Briggs, above n 8, 943.

${ }^{13}$ P Daillier, M Forteau \& A Pellet, Droit International Public ( $8^{\text {th }}$ ed, 2008) 342.

${ }^{14}$ A de La Pradelle, 'The Effect of War on Private Law Treaties' (1948) 2 ILQ 555; H Tobin, The Termination of Multipartite Treaties (1933) 22; C Hurst, 'The Effect of War on Treaties' (1921-22) 2 BYIL 38; M Politis, 'Effets de la Guerre sur les Obligations Internationales' (1911) Annuaire de l'Institut de droit International 200; J Moore, A Digest of International Law, vol 5 (1906) 381; A Pillet, Les Lois Actuelles de la Guerre (1901) 77.

${ }^{15}$ J Crawford (ed), Brownlie's Principles of International Law ( $8^{\text {th }}$ ed, 2012) 744-5; K Skubiszewski, 'Use of force by states. Collective security. Law of war and neutrality', in Sørenson, above n 7 , 739, 741-2. 
role of international law was limited to regulating, and sometimes prohibiting, certain methods of warfare, as well as to the treatment of combatants and non-combatants. ${ }^{16}$

The traditional view, prevailing at the time, ${ }^{17}$ was that treaties between warring states were automatically abrogated with the outbreak of war. It was for the parties to provide for the revival of pre-war treaties by subsequent agreement, as was done in the peace treaties referred to earlier. This no longer reflects the received view in international law. As is discussed below, by the middle of the twentieth century, a more nuanced understanding of the general position arose, away from a blanket presumption of discontinuity and towards the recognition that the outbreak of armed conflict does not ipso facto terminate or suspend the operation of treaties. Whether an armed conflict has such effect will depend on the nature of the treaty and that of the conflict. This has been the approach taken by the International Law Commission (ILC) in its recent consideration of the topic.

Such evolution in the law coincided with a broader shift in the international legal order, particularly after the Second World War. Most significantly for the present purposes, the resort to war as an instrument of foreign policy was declared unlawful by the Kellogg-Briand Pact of $1928,{ }^{18}$ and subsequently by the general prohibition on the resort to armed force enshrined in article 2, paragraph 4, of the Charter of the United Nations (except in the exercise of the right to self-defense (article 51)). ${ }^{19}$ Such general prohibition, together with the establishment of the collective security system under Chapter VII of the Charter, had the effect of re-orienting international law into being more directly concerned with the law of peace, ${ }^{20}$ even if it continued to regulate some aspects of warfare, for example, in the context of international humanitarian law. While key questions concerning the use of force, such as the legal definition and consequences of aggression, remained to be resolved, these took a backstage to broader developments in the law pertaining, for example, to the recognition and elaboration of fundamental international human rights norms.

This shift has been accompanied by a change in the nature of international

\footnotetext{
${ }^{16} \mathrm{~J}$ Dugard, International Law: A South African Perspective $\left(4^{\text {th }}\right.$ ed, 2012) 495, 519-21.

17 Primarily in continental jurisprudence but less so among the common law jurisdictions; see the discussion in A McNair, The Law of Treaties (1961) 699-728.

${ }^{18}$ General Treaty for the Renunciation of War, 27 August 1928, 94 LNTS 57.

${ }^{19}$ Dugard, above n 16, 495-6.

${ }^{20} \mathrm{~J}$ Brierly, The Law of Nations: An introduction to the international law of peace $\left(6^{\text {th }}\right.$ ed, 1963) 408; A Cassese, International Law ( $2^{\text {nd }}$ ed, 2005) 323-6.
} 
law itself. It is increasingly possible to speak of the existence of an international public law, rooted in multilateralism and placing greater emphasis on communitarian notions and values. ${ }^{21}$ These include the formal recognition of the class of legal obligations owed to the international community as a whole (erga omnes) ${ }^{22}$ in addition to the legal constraints on the actions of states imposed by peremptory norms (jus cogens) of international law. ${ }^{23}$ To this can be added the elaboration of structural rules of a secondary nature regulating such issues as validity, breach and the legal consequences of wrongful acts, ${ }^{24}$ as well as the emergence of the phenomenon of increased specialisation in international law. In some contexts, international law has become more regulatory in nature, as international action is increasingly taken through (and by) international organisations (including those dedicated to regional economic integration). Entire international legal frameworks, typically anchored in international organisations, have been developed in support of transnational, regional and even global interests, such as free trade, environmental protection, the protection and promotion of human rights, the protection of intellectual property rights and disarmament. ${ }^{25}$ It is increasingly difficult to conceive of states opting-out from such a web of legal norms simply as a consequence of their involvement in an armed conflict.

Also different from a century ago, international law is increasingly adjudicated. ${ }^{26}$ A standing international court has been in place (in different guises) for most of the last nine decades. Today, the International Court of Justice has a full and diverse docket involving international claims raised by states small and large. The jurisprudence of the court (and its predecessor) has played a key role in the solidification of international law as a distinct body of law. More recently, the number of international courts (typically with specialised jurisdiction) has increased. Furthermore, it is now common for international law rules contained in treaties to be referred to in transnational private litigation, particularly in the

${ }^{21}$ B Simma, 'From Bilateralism to Community Interest in International Law' (1994) 250 Recueil des Cours 217.

${ }^{22}$ Barcelona Traction, Light and Power Company, Limited (Belgium v Spain), Second Phase, Judgment, ICJ Reports 1970 p 3, para 33.

${ }^{23}$ Vienna Convention on the Law of Treaties, 22 May 1969, 1155 UNTS 331, Art 53 (VCLT); A Orakhelashvili, Peremptory Norms in International Law (2006) 7-35.

${ }^{24}$ Respectively in the VCLT and in the articles on the responsibility of states for internationally wrongful acts, GA Res 56/83, 12 Dec 2001, Annex.

${ }^{25}$ For an early discussion see W Friedmann, The Changing Structure of International Law (1964) 365-81.

${ }^{26}$ Dugard, above n 16, 451-3. 
context of commercial arbitrations. ${ }^{27}$ Even domestic courts are, in general, more receptive to international rules today. While there certainly may be room for improvement, in comparison to a time when international law was the province of diplomats and academics, it is today increasingly possible to view international law as a transactional discipline. The implication of this is that the question of the legal consequences of an armed conflict may be increasingly the subject of legal adjudication, as opposed to political accommodation.

There has also been a change in the nature of armed conflict itself. War is no longer declared. ${ }^{28}$ The legal existence of a state of war is now less a question of the characterisation of specific acts and more that of meeting thresholds of violence. ${ }^{29}$ While the classical inter-state conflict is not entirely a thing of the past, it is no longer the most common form of armed conflict. ${ }^{30}$ Non-international armed conflict-that is, conflict within a state as opposed to between states, and sometimes not even involving forces representing the state-is more prevalent today. ${ }^{31}$ This calls into question the relevance of existing international rules, since much of the practice of states and legal doctrine from which they are drawn is based on the traditional model of inter-state conflict. Contrary to the traditional view of war breaking out at a certain point in time, a conflict may exist de facto long before the international legal definition of armed conflict is satisfied. Traditional notions of armed conflict are further challenged by the concepts of 'asymmetric warfare' and the 'global war on terror.' ${ }^{32}$ To the extent that it is admitted that all such types of armed conflicts also affect treaties, their existence may potentially have a destabilising effect on the legal relations between states. It is against the background of such developments in the law and in the factual context of armed conflict that contemporary efforts to develop rules on the effects of armed conflicts on treaties are to be understood.

In the post-war period, the question of the effect of armed conflict on treaties

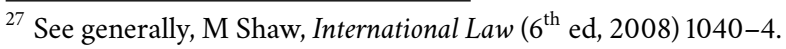

${ }^{28} \mathrm{Ibid}, 1122$.

${ }^{29}$ See the discussion below on the reference to 'protracted armed violence' in Prosecutor v. Duško Tadić, International Tribunal for the Former Yugoslavia, Appeals Chamber, Decision on the Defence Motion for Interlocutory Appeal on Jurisdiction (2 October 1995), para 70.

${ }^{30}$ Aust, above n 11, 310.

${ }^{31}$ C Gray, 'The Use of Force and the International Legal Order', in M Evans (ed), International Law ( $1^{\text {st }}$ ed, 2003) 589, 598-9; C Greenwood, 'The Law of War (International Humanitarian Law)' in Evans, 789, 814-16.

${ }^{32}$ S Chesterman, "The United Nations and the Law of War: Power and Sensibility in International Law' (2004-2005) 28 Fordham ILJ 531; O Gross \& F Ní Aoláin, Law in Times of Crisis: Emergency Powers in Theory and Practice (2006) 365-420.
} 
was first considered, albeit tangentially, during the process of the elaboration of the law of treaties. However, the states participating in the 1968-69 Vienna Conference declined to deal comprehensively with the issue, preferring instead to reserve, in a saving clause in what became article 75 of the VCLT, the legal position so as not to 'prejudge any question that may arise in regard to a treaty from...the outbreak of hostilities between States'. The topic was revisited two decades later (in a private context) by the Institute of International Law, which adopted an influential resolution in $1985 .{ }^{33}$ In 2004, the ILC turned its attention to the topic. This was relatively familiar territory since it had developed the preparatory text on the law of treaties, which served as the basis of negotiation at the Vienna Conference. A first reading of a set of draft articles on the effects of armed conflicts on treaties was completed in 2008 on the basis of the proposals of the first Special Rapporteur, Sir Ian Brownlie, following an extensive analysis of applicable state practice and doctrine. The final set of draft articles was adopted, on second reading, in 2011 (2011 articles) under the guidance of the second Special Rapporteur, the Swiss jurist Lucius Caflisch. ${ }^{34}$

The underlying premise of the 2011 articles is that, as a matter of principle, war does not ipso facto lead to the rupture of legal relations. ${ }^{35}$ More fundamentally, war does not, under the contemporary view, exist notionally outside of law in the sense that law would only apply to relations between states during times of peace. On the contrary, law is viewed as being able to tolerate war (at least in most cases). As already described, this position can be understood in a historical perspective as a manifestation of the broader shift in the reach of international law, which has taken place over the last century. It is also a function of the fact that the ILC typically errs in favour of the applicability of international law. One of its primary policy concerns in codifying and progressively developing international law has been the need to ensure the stability of treaty relations. This consideration was particularly acute when coming to the legal effect of war on treaties. $^{36}$

The complexity of the topic relates to the multiple dimensions in which it arises. As indicated earlier, war, or 'armed conflict' as it is referred to today, may affect not only the treaty relations between states involved in the conflict but also

\footnotetext{
33 (1985) 61(1) Annuaire de l'Institut de Droit International 1-27; (1985) 61(2) Annuaire de l'Institut de Droit International 199-255.

34 'Report of the International Law Commission on its Sixty-third Session', UN Doc A/66/10, 2011, $173 \mathrm{ff}$ (ILC Report).

${ }^{35}$ Ibid, 183, commentary to Part Two, Ch I.

${ }^{36}$ Ibid, para 1 of commentary to Art 3.
} 
their relations with third parties, even if to a different degree. A similar problem arises when looking at the effect of internal armed conflict, where other states are by definition third states. The ILC admitted that internal armed conflict may also, in some circumstances, have an effect on the treaties to which the state is a party. ${ }^{37}$ In doing so, it went beyond the scope of the VCLT, which is limited (in article 1) to treaties between states. A third potential complexity has to do with the question of the impact on treaties with international organisations. While the ILC chose to leave the matter aside, ${ }^{38}$ multilateral treaties that have international organisations as parties (in addition to states) are included within the purview of the 2011 articles to the extent that the articles apply to the treaty relations between states, which may be affected by an armed conflict. ${ }^{39}$

In defining armed conflict for purposes of the draft articles, the ILC looked beyond traditional definitions, typically based on the distinction between international and non-international armed conflict found in the Geneva conventions of 1949. It opted for a modified version of the definition formulated by the Appeals Chamber of the International Criminal Tribunal for Yugoslavia in the 1995 Tadic decision. ${ }^{40}$ The definition looks at armed conflict in functional terms as a 'situation in which there is resort to armed force between States or protracted resort to armed force between governmental authorities and organised armed groups. ${ }^{41}$ The qualifier 'protracted' serves to establish a minimum threshold of violence that needs to be reached before it can be said that an internal armed conflict may legally affect treaty relations. ${ }^{42}$ The degree of outside involvement in the internal conflict may also be a factor in ascertaining the potential impact on treaty relations. ${ }^{43}$ Such considerations were included to assuage concerns that the very recognition that internal armed conflict may affect treaties with third states was, in and of itself, potentially destabilising as it could call into question numerous treaties to which states undergoing internal strife are parties. ${ }^{44}$

As a matter of law, the notion that treaties may be terminated by armed conflict is implied in the VCLT, which, for example, foresees the invocation of a 'fundamental change of circumstances' as a ground for termination or

\footnotetext{
372011 Articles, Art 2(b).

${ }^{38}$ ILC Report, above n 34, 180, para 4 of commentary to Art 1.

392011 Articles, Art 2(a).

${ }^{40}$ Prosecutor v Duško Tadić, above n 29.

412011 Articles, Art 2(b).

${ }^{42}$ ILC Report, above n 34, 182-3, para 8 of commentary to Art 2.

${ }^{43} 2011$ Articles, Art 6(b).

${ }^{44}$ ILC Report, above n 34, 188, para 4 of commentary to Art 6.
} 
withdrawal in circumstances, inter alia, where 'the effect of the change is radically to transform the extent of obligations still to be performed under the treaty. ${ }^{45}$ It is conceivable that war too may have such an effect on a treaty (even if it is traditionally considered to be a distinct ground for termination or withdrawal). At the same time, as described earlier, a conceptual shift in the law has occurred over the last century so that it is no longer accepted that war would automatically do so.

The contemporary default position is reflected in article 3 of the 2011 articles which provides that, as a question of general international law, the 'existence of an armed conflict does not ipso facto terminate or suspend the operation of treaties'. It is worth noting that the ILC consciously did not swing the pendulum to the opposite extreme by adopting a general presumption in favour of the continuity of treaties. Not only did it feel that such a stance was not (yet) supported in the practice of states, or for that matter in the legal doctrine, it would have meant that its task would have been to establish when such presumption would not apply, i.e. the conditions for discontinuity of treaties-something which would not have been conducive to the stability of treaty relations. ${ }^{46}$ Instead, it opted for a general presumption against discontinuity, which it took as a nod in favour of treaty stability. The emphasis, therefore, is placed on the conditions for continuity of treaties by providing practical guidance to the law-applier trying to ascertain the perturbative effect of a particular conflict on a particular treaty.

As a general assertion, priority is given to the terms of the treaty itself. If a treaty contains a provision regulating its continuity in the context of an armed conflict, such provision governs. ${ }^{47}$ Some treaties are meant to apply in times of armed conflict, as in the case of treaties establishing rules on the conduct of hostilities and the protections under international humanitarian law. Others might do so more indirectly. For example, a number of international human rights treaties anticipate the non-derogation of certain rights even in times of national emergency, presumably including armed conflict. ${ }^{48}$ By definition, such rules apply during-as opposed to being displaced by-the armed conflict. ${ }^{49}$ It is

\footnotetext{
${ }^{45}$ VCLT, Art 62.

${ }^{46}$ ILC Report, above n 34, 183-4, para 1 of commentary to Art 3.

472011 Articles, Art 4.

${ }^{48}$ For example, International Covenant on Civil and Political Rights, 16 December 1966, 999 UNTS 171, Art 4(1).

${ }^{49}$ Legality of the Threat or Use of Nuclear Weapons, Advisory Opinion, ICJ Reports 1996, p 226, para 25; Legal Consequences of the Construction of a Wall in the Occupied Palestinian Territory, Advisory Opinion, ICJ Reports 2004 p 136, para 106.
} 
also recognised that the existence of an armed conflict does not deprive the states involved therein of the capacity to conclude international agreements during the conflict, ${ }^{50}$ such as for the exchange of prisoners or pertaining to the establishment of humanitarian safe-havens or passage. Nonetheless, as indicated earlier, the vast majority of treaties are adopted on the assumption of the existence of peaceful relations, and therefore without any provision being made for the event of war.

Nor is it usually feasible to identify an intention of the parties at the time of adoption of the treaty, as to the question of what will happen if war were to break out. At most, any such intention is likely to be constructed and would, at any rate, be one of several factors to be considered, even if implicitly. In other words, the treaty would have to be interpreted, in accordance with the existing rules on treaty interpretation so as to draw any relevant inferences as to the legal outcome of war between state parties to the treaty. ${ }^{51}$ Articles 31 and 32 of the VCLT provide a toolkit for the law-applier seeking to interpret a treaty. The emphasis is placed less on a subjective approach (implied in assertions of the intention of the parties) and more on the objective meaning of the treaty. ${ }^{52}$

If an analysis of the terms and meaning of the treaty itself proves inconclusive then the enquiry shifts to considerations extraneous to the treaty. The ILC identified two sets of factors that may be of particular relevance, the first related to the nature of the treaty and the second to the characteristics of the armed conflict. ${ }^{53}$ It should be noted that such factors are presented in a non-exhaustive manner and it is to be understood that which particular factors are relevant, and to what extent, may vary from treaty to treaty and from conflict to conflict. ${ }^{54}$

In considering the 'nature' of the treaty, the law-applier would look at its subject-matter, its object and purpose, its content and the number of parties. To assist with such enquiry, the ILC developed a non-exhaustive list of categories of treaties (contained in an annex to the articles) the subject-matter of which implies that they continue in operation, in whole or in part, during an armed conflict. As already indicated, treaties on the law of armed conflict, including those relating to international humanitarian law, would carry such implication. Other categories identified by the ILC include: those declaring, creating or regulating a permanent regime (including those establishing or modifying land and maritime

\footnotetext{
${ }^{50} 2011$ Articles, Art 8(1).

${ }^{51}$ Ibid, Art 5.

${ }^{52}$ M Villiger, Commentary on the 1969 Vienna Convention on the Law of Treaties (2009) 426-427 and 435-436; R Gardiner, Treaty Interpretation (2008) 141-202.

${ }^{53} 2011$ Articles, Art 6.

${ }^{54}$ ILC Report, above n 34, 187, para 2 of commentary to Art 6.
} 
boundaries); multilateral law-making treaties; treaties on international criminal justice; those pertaining to friendship, commerce and navigation and including agreements on private rights; treaties for the protection of international human rights and the protection of the environment, international watercourses and aquifers; constituent instruments of international organisations adopted in treaty form; treaties relating to the international settlement of disputes, and treaties concerning diplomatic and consular relations. Some categories were included because it was assumed that they typically would need to continue to operate during an armed conflict (e.g. treaties on diplomatic and consular relations include provisions on the protection of diplomatic and consular property during times of war). Other categories were included more as a matter of general policy, owing to the fundamental interests at stake. These pertained, for example, to the protection of the environment and the legal sanctity of permanent regimes and territorial boundaries.

The second leg calls for a consideration of the armed conflict which requires, inter alia, an analysis which would take into account the characteristics of the conflict, including its territorial extent, its scale and intensity, duration, and, in the case of internal armed conflict, the degree of outside involvement. ${ }^{55}$ Once again, the law applier is presented with a continuum of possibilities: the more intense and widespread a conflict, the more likely its impact on a treaty, and so on. A further part of the examination pertains to the question of the legality of the conflict under international law. As mentioned earlier, contemporary international law limits the lawfulness of the resort to armed force to a few accepted grounds. The articles recognise that a state acting in exercise of its inherent right of individual or collective self-defence in accordance with the Charter of the United Nations is entitled to suspend in whole or in part the operation of a treaty to which it is a Party insofar as that operation is incompatible with the exercise of that right. ${ }^{56}$ Furthermore, the 2011 articles expressly limit the possibility of an aggressor state (as defined under international law) benefiting from any right, arising under the articles, to terminate, withdraw from, or suspend the operation of a treaty owing to the existence of the armed conflict. ${ }^{57}$

Once it is established that an armed conflict has affected a treaty, the question arises as to the extent of such effect. This is to be considered on two levels. First, what exactly is the effect on the treaty? Here, the ILC identified three possible

\footnotetext{
552011 Articles, Art 6(b).

${ }^{56}$ Ibid, Art 14.

${ }^{57}$ Ibid, Art 15.
} 
outcomes-termination, withdrawal from or suspension of the operation of the treaty-without providing guidance on when one would be more appropriate than the other. While withdrawal is a unilateral act undertaken voluntarily, the termination and suspension of operation of the treaty may also occur automatically, by operation of law, regardless of any assertions to the contrary. The 2011 articles provide for a procedure (discussed below) to be followed by a state intending to terminate, withdraw from or suspend the operation of a treaty as a consequence of armed conflict, in case the treaty does not itself provide such a procedure.

The second sense in which the extent of the effect of the armed conflict is to be considered pertains to whether the entire treaty is affected, or only parts thereof. The 2011 articles envisage the possibility of the separability of treaty provisions, ${ }^{58}$ where the treaty contains clauses that can be separated from the remainder of the treaty without affecting its application and those clauses were not an essential basis for consent of the other parties to be bound by the treaty, and where continued performance of the treaty would not be unjust. In other words, to the three potential outcomes already referred to should be added the possibility that a treaty might continue in operation, albeit in partial form, to the extent that those provisions which were affected by the conflict could validly be severed from the treaty. The provision, which was modeled on its equivalent in the VCLT (article 44), was introduced to moderate the impact of the 2011 articles. ${ }^{59}$

It is possible that a state may, through waiver or estoppel (giving rise to the assumption of acquiescence) lose its right to terminate, withdraw from or suspend the operation of, the treaty as a consequence of an armed conflict. ${ }^{60} \mathrm{Such}$ possibility was included in recognition that 'a minimum of good faith must prevail even in times of armed conflict.' ${ }^{61}$ Conversely, the 2011 articles also admit that, subsequent to the armed conflict, the states involved can regulate, on the basis of an agreement, the revival of treaties that have been terminated or suspended as a consequence of the armed conflict. ${ }^{62}$ As alluded to earlier, this has in fact occurred in a number of peace treaties following major wars. Furthermore, even where no such agreement is in place, it is nonetheless envisaged that suspended treaties might resume their operation following the conclusion of the conflict. ${ }^{63}$

\footnotetext{
${ }^{58}$ Ibid, Art 11.

${ }^{59}$ ILC Report, above n 34, 192-3, para 3 of commentary to Art 11.

${ }^{60} 2011$ Articles, Art 12.

${ }^{61}$ ILC Report, above n 34, 193, para 1 of commentary to Art 12.

${ }^{62} 2011$ Articles, Art 13(1).

${ }^{63}$ Ibid, Art 13(2).
} 
It is also worth noting that the 2011 articles are limited in scope to the effect on treaties. Even if their application results in the perturbation of a treaty, this cannot impair in any way the duty of any State to fulfill any obligation embodied in the treaty to which it would be subject under international law independently of that treaty', ${ }^{\prime}$ i.e. by operation of customary international law. For example, the Ethiopia-Eritrea Claims Commission considered customary international law, including customary international humanitarian law, to be the applicable law on which to base its decisions. ${ }^{65}$ This is not to say that customary obligations are not affected by war, but rather that the 2011 articles simply do not deal with that issue.

While the ILC's primary focus was on developing a set of dispositive rules, which it envisaged being applied equally during and after an armed conflict, it also proposed a notification requirement. ${ }^{66}$ Under the terms of the envisaged procedure, a state intending to exercise its right, in accordance with the articles, to terminate or withdraw from a treaty or to suspend its operation, would have to notify the other state party or parties to the treaty of such intention. ${ }^{67}$ The notice would, unless it provides otherwise, take effect upon receipt. ${ }^{68}$ Any party to the treaty may, within a reasonable time, object to the proposed termination, withdrawal or suspension. This it would do in accordance with the rules of the treaty itself or those of general international law (such as in the VCLT) if no provision is made in the treaty. ${ }^{69}$ Once such objection is raised, then the states concerned are to seek a solution through one of the means for peaceful settlement of disputes listed in article 33 of the Charter of the United Nations, ${ }^{70}$ namely negotiation, enquiry, mediation, conciliation, arbitration, judicial settlement, resort to regional agencies or arrangements, or other peaceful means. No reference is made to timing, since it may be likely that the resort to peaceful settlement might realistically only take place once the conflict has ended. ${ }^{71}$ Nonetheless, the ILC took the view that international obligations to resolve disputes peacefully were not ipso facto ended by war, ${ }^{72}$ even if their performance may be constrained. Accordingly, such obligations would continue to apply also

\footnotetext{
${ }^{64}$ Ibid, Art 10.

${ }^{65}$ Prisoners of War, Partial Award of 1 July 2003, XXVI RIAA p 23, 40.

${ }^{66} 2011$ Articles, Art 9.

${ }^{67}$ Ibid, Art 9(1).

${ }^{68}$ Ibid, Art 9(2).

${ }^{69}$ Ibid, Art 9(3).

${ }^{70}$ Ibid, Art 9(4).

${ }^{71}$ ILC Report, above n 34, 191, para 6 of commentary to Art 9.

722011 Articles, Art 9(5).
} 
to any legal disputes regarding the effect of the conflict on treaties. ${ }^{73}$

The provision was modeled on its equivalent in the VCLT (article 65). The analogy is, however, somewhat strained: the considerations implied in a requirement that a procedure be followed are different for times of peace than those during armed conflict. It might just not be possible, in the fog of war, for a state to ensure that it has given the proper notice of its intention to terminate, withdraw from or suspend the operation of its treaties to (or, for that matter, to object within a reasonable time to a similar assertion from) its opposing party. Such requirement is arguably more compelling in the case of a state engaged in armed conflict giving notice to a third state (not party to the conflict) that a treaty between them has been affected by the conflict. It is also to be assumed that the provision only has a prospective effect since it can hardly be the case that states that engaged in an armed conflict prior to the adoption of the 2011 articles could be said to have not followed the proposed procedure. What is less clear is what inference to draw if the proposed procedure is not followed. Making the notification procedure a legal requirement would imply the loss of the right to claim if the notification is not given. Yet, non-performance of the notification procedure might not amount to waiver or estoppel under the articles since it does not necessarily constitute express agreement or even acquiescence in the status quo. Even if it were, a loss of a right to claim under such circumstances would deprive the general rule in article 3 of practical effect. Given the context in which the state would be required to act (i.e. war), such outcome would be particularly harsh. All of this seems to point, in the view of the present writer, to the conclusion that the notification procedure is recommendatory in nature, and should be understood within the general rubric of the continuing obligation on states to resolve their disputes by peaceful means.

Upon adopting the articles, the ILC recommended to the General Assembly that it take note of the articles in a resolution to which they would be annexed and decide at a later stage whether to adopt them in the form of an international convention. ${ }^{74}$ The General Assembly followed suit and took note of the articles in resolution 66/99 of 9 December 2011, to which they were annexed, and commended them to the attention of governments. The Assembly also decided to return, in 2014, to the question of what form the articles might eventually take. While the articles were formulated in a form suitable for a convention, the likelihood of that step being taken is at present low. Since their scope

\footnotetext{
${ }^{73}$ ILC Report, above n 34, 191, para 7 of commentary to Art 9.

${ }^{74}$ Ibid, 174.
} 
ratione materiae is broader than that of the VCLT, their suitability as a protocol to that convention is doubted. The relatively obscure nature of the topic makes it also less likely that states will seek to adopt a convention thereon anytime soon. This suggests that the 2011 articles will likely remain, for the foreseeable future, an authoritative statement by the international community detailing, in an expository manner, the rules of general international law on the legal effects of armed conflicts on treaties. 